\title{
Attitudes of women after the age of 50 towards preventive screening
}

\author{
Hanna Skórzyńska', Marlena Krawczyk-Suszek², Teresa B Kulik', Anna Pacian', \\ Agata Stefanowicz ${ }^{3}$, Anna Skowronek ${ }^{3}$ \\ ${ }^{1}$ Department of Public Health, Faculty of Health Sciences, Medical University of Lublin, Lublin, Poland \\ 2 Department of Physiotherapy, Faculty of Medicine, University of Information Technology and Management, Rzeszow, Poland \\ ${ }^{3}$ Student scientific circle at the Department of Public Health, Medical University of Lublin, Lublin, Poland
}

Attitudes of women after the age of 50 towards preventive screening. Skórzyńska H, Krawczyk-Suszek M, Kulik T. B, Pacian A, Stefanowicz A, Skowronek A. Ann Agric Environ Med. 2017; 24(4): 624-627. doi: 10.5604/12321966.1232768

\begin{abstract}
Introduction. Prevention is one of the major branches of the health sector. The National Health Programme encompasses main risk factors, elimination of which may lead to a reduced incidence of illnesses in the society. At the same time, the criteria of selecting people eligible for preventive screening are established according to risk groups determined by sex, as well as age in the population of women. The perimenopausal and menopausal period contributes to occurrence of numerous systemic diseases and to an increased risk of illnesses, especially cancers.

Objective. The objective of the research was to evaluate the performance of preventive screening tests of women after 50 aimed at early detection of cervical and breast cancer. Furthermore, the research estimated frequency of pathological lesions detected and regularity of their monitoring. Materials and methods. The research covered 150 women after 50 years of age. The database was statistically examined with STATISTICA software.

Results. A low percentage of the respondents, in comparison to the risk increasing with age, had a Pap test (61.3\%) and mammography (51.3\%) in the last two years. In the case of women whose latest Pap test or mammography showed abnormalities and was the basis for diagnosing pathological lesions, $69.2 \%$ of them were under regular medical supervision if abnormalities were identified by a Pap test and $68.7 \%$ if lesions were detected in breast structure. Conclusions. In the examined group we observed a small percentage of women undergo Pap tests and mammography. Furthermore, medical recommendations regarding early detection of cancers are frequently ignored and disregarded by patients.
\end{abstract}

\section{Key words}

mammography, Pap test, preventive screening

\section{INTRODUCTION}

Broadly understood prevention is one of the crucial factors determining the health of society, and satisfactory statistics of early detection of illnesses support the promotion of preventive behaviour. People from high risk groups are strongly advised to undergo preventive screening. Such high risk groups include women in the menopausal period.

Menopause is a term which refers to the time of the last menstruation. However, it can be diagnosed not earlier than 6 months after the last menstrual flow [1]. Menopause is usually preceded by the premenopausal period lasting about 5-6 years, on average. The symptoms observed during this period are: a decrease in the hormonal activity of ovaries and an accompanying quick reduction in the amount of ovarian follicles [2]. Menopausal ailments are triggered by changes occurring in a woman's body which affect almost all systems in the body and produce symptoms of a vasomotor character [3]. Typical problems of the menopausal period also include ailments of the urogenital system, disturbance in libido and the mental sphere, changes in the connective tissue, metabolic disorders, obesity, as well as diseases of the cardiovascular system. Another significant menopausal effect is an increased risk of cancer. In women after the age of 45 ,

Address for correspondence: Marlena Krawczyk-Suszek, Department of Physiotherapy, Faculty of Medicine, University of Information Technology and Management, Rzeszow

E-mail:m.krawczyk.umlub@gmail.com

Received: 8 April 2014; accepted: 11 September 2014; first published on January 2017 there is a notable and constant increase in the occurrence of cancers of the breast, lungs, cervix, stomach, ovaries, uterus, among others [4]. These diseases accompanying the menopausal period, have a considerable impact on the quality of life of women.

As regards advisability of preventive measures and the time of their beginning, the menopausal period is the right moment to estimate risk factors, and to undertake a series of screening tests aimed at detecting illnesses typical of this period. A significant role in preventive medicine is entrusted to general practitioners, as well as to specialists such as gynaecologists and oncologists. During annual medical checks, women after 40 should undergo regular screening tests aimed at early detection of cancer, heart diseases, diabetes, mental illnesses, as well as thyroid disorders [5].

The criteria for selecting a group for preventive screening tests, as well as the time of their performance, are important knowledge for patients who sometimes decide on their own about the need to undergo screening. Early diagnostics and enhancing the effectiveness of treatment of cervical and breast cancers constitute the Operational Objective No. 15, formulated in the National Health Programme [6]. In accordance with the recommendations of the Cervical Cancer Prevention Programme, women aged between 25-59, who have not had a Pap test performed in recent 3 years, can take part in screening [7]. Women over the age of 50, with normal results of a cervical smear, should repeat the Pap test every 2 years, while women with abnormalities detected previously in a cervical smear or after cervix operations, should be tested 
more frequently (every year), depending on the doctor's recommendations. Health education plays an important role as an indispensable element of the health promotion process in society, especially in high risk groups [8].

Early detection of pathological lesions and early treatment save life, as survival depends on the advancement level of detected abnormalities. Precancerous condition and cervical cancer require specialized medical examinations and treatment, but the first test performed is a Pap smear [9]. Unfortunately, this test is not a perfect tool because there is a high share of falsely positive and falsely negative results, reaching $30-70 \%$, as well as low interlaboratory compatibility, which impairs effectiveness of the screening idea itself [10].

\section{OBJECTIVE}

The aim of the research was to evaluate the awareness of women aged over 50 regarding preventive screening recommended in the menopausal period. The research also estimated the frequency of screening tests carried out and disorders detected.

\section{MATERIALS AND METHOD}

The research was conducted from 1 July - 10 September 2013 in the Lublin province of eastern Poland. The study was conducted in randomly selected out-patient clinics, by applying a random class selection. In order to ensure that the group was representative, the criteria for selecting the surveyed group were female gender and age over 50 . The research covered 150 women and was based on an anonymous questionnaire designed by the author. The questionnaire contained questions about attitudes of the surveyed women towards preventive screening, and about their evaluation of availability and performance of screening tests. The database compiled was statistically examined with STATISTICA PL 10 software.

\section{RESULTS}

The majority of women who agreed to take part in the survey lived in urban areas (76\%), while a small percentage resided permanently in rural areas (24\%). The education structure of the surveyed group was as follows: the highest percentage (51.3\%) of the respondents had secondary education, $25.3 \%$ completed vocational education, 9.3\% finished primary schools, and $14 \%$ received higher education.

The Pap test is the primary test used in prophylactic treatment. The women were asked whether any abnormalities were detected during their Pap tests conducted within the last 2 years. Both variables are dependent $(p=0,0000<\alpha=0.05)$. Among the respondents who had a Pap test in the last 2 years, $14.1 \%$ received results confirming lesions in the cervix. The remaining group (85.9\%) received normal results of the Pap smear. In the total surveyed group, $38.7 \%$ did not have a Pap smear in the last 2 years. According to the study, a still high percentage of women do not perform preventive research (Tab. 1)

Among women aged over 50 who had had mammography performed in the last 2 years, $20.8 \%$ obtained results
Table 1. Frequency of having Pap tests vs. detectability of lesions

\begin{tabular}{|c|c|c|c|c|c|}
\hline & \multicolumn{5}{|c|}{$\begin{array}{l}\text { Contingency table (Sheet 2); Number of marked cells }>10 \\
\text { Pearson's } \mathrm{Chi}^{2}=150.00 ; \mathrm{df}=2 ; \mathrm{p}=0.0000<\mathrm{a}=0.05\end{array}$} \\
\hline & \multirow{2}{*}{$\begin{array}{l}\text { Performance of } \\
\text { Pap test in the } \\
\text { last } 2 \text { years }\end{array}$} & \multicolumn{3}{|c|}{ Lesions detected in Pap test } & \multirow{2}{*}{$\begin{array}{l}\text { Total in } \\
\text { the line }\end{array}$} \\
\hline & & yes & no & not applicable & \\
\hline Number & yes & 13 & 79 & 0 & 92 \\
\hline$\%$ of the line & & $14.13 \%$ & $85.87 \%$ & $0.00 \%$ & \\
\hline$\%$ of the total & & $8.67 \%$ & $52.67 \%$ & $0.00 \%$ & $61.33 \%$ \\
\hline Number & no & 0 & 0 & 58 & 58 \\
\hline$\%$ of the line & & $0.00 \%$ & $0.00 \%$ & $100.00 \%$ & \\
\hline$\%$ of the total & & $0.00 \%$ & $0.00 \%$ & $38.67 \%$ & $38.67 \%$ \\
\hline Number & Total & 13 & 79 & 58 & 150 \\
\hline$\%$ of the total & & $8.67 \%$ & $52.67 \%$ & $38.67 \%$ & \\
\hline
\end{tabular}

suggesting pathological lesions in breasts. The remaining group obtained satisfactory results (no abnormalities $79.2 \%)$. In the total group of the surveyed women at risk of breast cancer, almost half of them did not have their breasts scanned in the last 2 years (48.7\%). Frequency of undergoing mammography is positively correlated with detectability of lesions $(\mathrm{p}=0,0000<\alpha=0.05)$. The frequency of mammography in the test group was low (Tab. 2).

Table 2. Frequency of having mammography vs. detectability of lesions

\begin{tabular}{|c|c|c|c|c|c|}
\hline & \multicolumn{5}{|c|}{$\begin{array}{l}\text { Contingency Table; No. of marked cells }>10 \\
\text { Pearson's } \mathrm{Chi}^{2}=150.000 ; \mathrm{df}=2 ; \mathrm{p}=0.0000<\mathrm{alfa}=0.05\end{array}$} \\
\hline & \multirow{2}{*}{$\begin{array}{l}\text { Performance of } \\
\text { mammography } \\
\text { in the last } 2 \text { years }\end{array}$} & \multicolumn{3}{|c|}{ Lesions detected in mammography } & \multirow{2}{*}{$\begin{array}{l}\text { Total in } \\
\text { the line }\end{array}$} \\
\hline & & yes & no & not applicable & \\
\hline Number & YES & 16 & 61 & 0 & 77 \\
\hline$\%$ of the line & & $20.78 \%$ & $79.22 \%$ & $0.00 \%$ & \\
\hline$\%$ of the total & & $10.67 \%$ & $40.67 \%$ & $0.00 \%$ & $51.33 \%$ \\
\hline Number & NO & 0 & 0 & 73 & 73 \\
\hline$\%$ of the line & & $0.00 \%$ & $0.00 \%$ & $100.00 \%$ & \\
\hline$\%$ of the total & & $0.00 \%$ & $0.00 \%$ & $48.67 \%$ & $48.67 \%$ \\
\hline Number & Total & 16 & 61 & 73 & 150 \\
\hline$\%$ of the total & & $10.67 \%$ & $40.67 \%$ & $48.67 \%$ & \\
\hline
\end{tabular}

Detection of abnormalities during preventive screening must be followed by further in-depth diagnostics of the lesion, confirmation of diagnosis, and decision on the type of treatment. Physicians frequently recommend regular monitoring and observation of the identified lesions. In the surveyed group of women whose mammography showed abnormalities in breast structure, $68.7 \%$ remained under permanent medical supervision and monitoring by the physician in charge. The remaining percentage $(31.2 \%)$ of women with diagnosed abnormalities did not undergo further regular monitoring. Among the respondents (40.7\%) whose previous mammography gave satisfactory results, $4.9 \%$ had subsequent regular medical supervision, while others did not conduct regular health checks. (Tab. 3)

On the European continent there are ca. 60,000 new cases of cervical cancer diagnosed every year, about half of which are fatal. The main cause of such statistics is late detection of the disease. [15] Pathological lesions in the cytology of cells taken from the cervix occur not only among older women, but also in younger groups. In the etiology of cervical 
Table 3. Detectability of lesions in mammography vs. regularity of monitoring

\begin{tabular}{|c|c|c|c|c|}
\hline \multirow{3}{*}{$\begin{array}{l}\text { Lesions } \\
\text { detected in } \\
\text { mammography }\end{array}$} & \multicolumn{4}{|c|}{$\begin{array}{l}\text { Summary bipartite Table: frequencies observed } \\
\text { Pearson's } \mathrm{Chi}^{2}=78.879 ; \mathrm{df}=4 ; \mathrm{p}=0.0000<0.05\end{array}$} \\
\hline & \multicolumn{3}{|c|}{ Regularity of monitoring } & \\
\hline & $\begin{array}{c}\text { Regular } \\
\text { monitoring in } \\
\text { accordance } \\
\text { with doctor's } \\
\text { recommendation }\end{array}$ & $\begin{array}{l}\text { No regular } \\
\text { monitoring }\end{array}$ & $\begin{array}{l}\text { Not } \\
\text { applicable }\end{array}$ & $\begin{array}{l}\text { Total in the } \\
\text { line }\end{array}$ \\
\hline YES & 11 & 5 & 0 & 16 \\
\hline$\%$ of the line & $68.75 \%$ & $31.25 \%$ & $0.00 \%$ & \\
\hline$\%$ of the total & $7.33 \%$ & $3.33 \%$ & $0.00 \%$ & $10.67 \%$ \\
\hline NO & 3 & 3 & 55 & 61 \\
\hline$\%$ of the line & $4.92 \%$ & $4.92 \%$ & $90.16 \%$ & \\
\hline$\%$ of the total & $2.00 \%$ & $2.00 \%$ & $36.67 \%$ & $40.67 \%$ \\
\hline NOT APPLICABLE & 5 & 1 & 67 & 73 \\
\hline$\%$ of the line & $6.85 \%$ & $1.37 \%$ & $91.78 \%$ & \\
\hline$\%$ of the total & $3.33 \%$ & $0.67 \%$ & $44.67 \%$ & $48.67 \%$ \\
\hline Total & 19 & 9 & 122 & 150 \\
\hline$\%$ of the total & $12.67 \%$ & $6.00 \%$ & $81.33 \%$ & $100.00 \%$ \\
\hline
\end{tabular}

cancer, a significant role is attributed to persistent HPV infection (Human Papilloma Virus), especially by highly carcinogenic strains. Therefore, detection of an abnormality and surgery must be followed by further checks and regular monitoring. In the examined group of women whose previous result of a Pap smear was unsatisfactory and indicated abnormalities in the cervix, 69.2\% had further regular medical check-ups, whereas other women from the high risk group did not undergo subsequent regular tests (30.8\%). Only $7.6 \%$ respondents with satisfactory Pap smear results remained under further regular supervision of a gynaecologist. Most of the surveyed women took a doctor's advice to keep controlling their health. This is the proper response of the female population (Tab. 4).

Table 4. Detectability of lesions in a Pap test vs. regularity of monitoring

\begin{tabular}{|c|c|c|c|c|}
\hline \multirow{3}{*}{$\begin{array}{l}\text { Lesions detected } \\
\text { in Pap test }\end{array}$} & \multicolumn{4}{|c|}{$\begin{array}{l}\text { A summary bipartite Table: frequencies observed } \\
\text { Pearson's } \mathrm{Chi}^{2}=62.501 ; \mathrm{df}=4 ; \mathrm{p}=0.0000<0.05\end{array}$} \\
\hline & \multicolumn{3}{|c|}{ Regularity of monitoring } & \multirow[b]{2}{*}{$\begin{array}{l}\text { Total in the } \\
\text { line }\end{array}$} \\
\hline & $\begin{array}{l}\text { Regular monitoring } \\
\text { in accordance } \\
\text { with doctor's } \\
\text { recommendation }\end{array}$ & $\begin{array}{l}\text { No regular } \\
\text { monitoring }\end{array}$ & $\begin{array}{c}\text { Not } \\
\text { applicable }\end{array}$ & \\
\hline YES & 9 & 4 & 0 & 13 \\
\hline$\%$ of the line & $69.23 \%$ & $30.77 \%$ & $0.00 \%$ & \\
\hline$\%$ of the total & $6.00 \%$ & $2.67 \%$ & $0.00 \%$ & $8.67 \%$ \\
\hline NO & 6 & 2 & 71 & 79 \\
\hline$\%$ of the line & $7.59 \%$ & $2.53 \%$ & $89.87 \%$ & \\
\hline$\%$ of the total & $4.00 \%$ & $1.33 \%$ & $47.33 \%$ & $52.67 \%$ \\
\hline NOT APPLICABLE & 4 & 3 & 51 & 58 \\
\hline$\%$ of the line & $6.90 \%$ & $5.17 \%$ & $87.93 \%$ & \\
\hline$\%$ of the total & $2.67 \%$ & $2.00 \%$ & $34.00 \%$ & $38.67 \%$ \\
\hline Total & 19 & 9 & 122 & 150 \\
\hline$\%$ of the total & $12.67 \%$ & $6.00 \%$ & $81.33 \%$ & $100.00 \%$ \\
\hline
\end{tabular}

DISCUSSION
Breast cancer,
of women in P
Breast Cancer P
identification a
according to
mammographs
of awareness
decrease the mo
since the percen
have mammog
of the examine
breast structur
of medical doc
Istitute of the
Poland, reveale
According to th
had no changes.
death rate resul
is important to
women to und
evaluation of po
Actions directe
at prevention of
are among the
sector. Consequ
promotion of the
Cancer as mult
[15]. Preventive
rate, but availab
in various enviro
States Preventive
the significance
beginning from
prevention and
screening tests
Woźniak [17].
women should a
the significance
(66\%); however,
a rare phenome
A mong the
a

Among the surveyed group of women, $61.3 \%$ had undergone a cervical smear test during the last 2 years. About 9\% had some disturbing changes. Spaczyński et al. present in their surveys a similar regularity of preventive examination in order to detect cervical cancer. $38 \%$ of the examined women avoided undergoing cervical smear test. Statistical interpretation of the screening method conducted within the framework of the Population Cervical Cancer Prevention Treatment Programme 2007-2009 conveyed that, on average, $24.24 \%$ of invited women underwent the cervical smear test [19]. In the research carried out by Nowicki, Borowa and Maruszak, 29.1\% of women associated with medicine by their profession claimed that they seldom consulted gynaecologists. Furthermore, $94.2 \%$ of women having a medical profession and $93.3 \%$ not associated with medicine, denied participation in screening aimed at the detection of cervical cancer [20].

Cervical cancer is the second most frequent malignant tumour of the genitalia in women. In the Third World countries the statistics are terrifying - the death rate due to cervical cancer reaches $80 \%$. However, no screening aimed 
at early detection is ever conducted there. Mortality caused by cervical cancer is a consequence of irregular (or lack of) preventive screening $[21,22]$. It is known that most women around the world have never participated in preventive screening tests and will not be treated if pathological lesions occur [23]. The need to educate society about proper healthpromoting behaviour is the primary objective of the health sector. Health-promoting behaviour encompasses habits, customs and attitudes, frequently originating in culture of a social group, or even of a family, which is the smallest social unit surrounding an individual and influencing him or her, especially as regards health. It contributes to the development and consolidation of a lifestyle which is one of the major factors determining the health condition of an individual. Proper health-promoting behaviour - a healthy lifestyle - is a factor reducing the risk of diseases, including cervical cancer or other malignant tumours [24].

The research carried out demonstrates the necessity to educate all age groups in society regarding prevention, diagnostics and recommendations for treatment of detected abnormalities. These goals are even more important, because in the surveyed group a negligent attitude of patients was noted towards the recommendations of a physician, or disregard of the necessity to follow them.

\section{CONCLUSIONS}

1. Preventive tests aimed at detecting cervical cancer are performed most frequently (61.3\%), followed by mammography (51.3\%).

2. In their attitudes towards prevention, the majority of the surveyed women exhibited a lack of strong habits of regular health monitoring.

3. There is a need for extensive educational actions, as well as for greater involvement of the health sector, aimed at development of an active attitude and regular monitoring of women's health.

\section{REFERENCES}

1. Bokiniec M. Menopauza. Przegląd Menopauzalny 2008; 3: 144-147.

2. Driancourt MA. Gouegeon A. Royere D. et al. Ovarian function. In: Reproduction in Mammals and Man. Thiblaut C, Levasseur MC, Hunter RHF [ed.]. Ellipses. Paris 1993, p. 281-305.
3. Utian WH. The true clinical features of postmenopause and oophorectomy and their response to oestrogen therapy. South African Med. J 1972; 46: 732-7.

4. Petryński T. Stachowiak G. Stetkiewicz T. Rola ginekologa w okresie pre- i około menopauzalnym. Przegląd Menopauzalny 2007; 2: 63-69

5. Pertyński T. Stetkiewicz T. Perimenopauza. In: Diagnostyka i terapia wieku menopauzalnego. Pertyński T [ed.], Urban \& Partner, Wrocław 2004, p. 313-22.

6. http://www2.mz.gov.pl/wwwfiles/ma_struktura/docs/zal_urm_ npz_90_15052007p.pdf ( $3^{\text {rd }}$ march 2014)

7. http://www.nfz.gov.pl/new/index.php?katnr=6\&dzialnr=145\&art $\mathrm{nr}=4659\left(3^{\text {rd }}\right.$ march 2014)

8. Słońska Z. Karski B. Promocja zdrowia. Wyd. Sanmedia, Warszawa 1995.

9. Malarewicz A. Rokita W. Effectiveness of routinely repeated prophylactic tests in cervical carcinoma. 10th International Meeting of Gynaecological Oncology. Coimbra, Portugal: Monduzzi Editore 26 April-2 May 1997. 1997, 47-50.

10. Fahey M. Irwig L. Macaskill P. Meta-analysis of Pap test accuracy. Am J Epidemiol. 1995, 141, 680-689.

11. Tabar L. Tot T. Dean P. Rak piersi. Wczesne wykrywanie przy użyciu mammografii. Wyd. MediPage, Warszawa 2010.

12. Surdyka D. Monitorowanie losów pacjentek- wykorzystywanie SIMP. Szkolenie dla realizatorów. Populacyjny Program Wczesnego Wykrywania Raka Piersi. Lublin 29.04.2008.

13. Nowicki A., Stogowska I. Wczesne wyniki badania profilaktycznego wykrywania raka piersi. Ginekol Pol. 2007, 78, s. 464-470.

14. Zasada-Cedro K. Cieślińska-Wilk G. Lubiński J. [et al.]. Badania profilaktyczne sutka poszerzone o wywiad genetyczny. Część I. Badania przesiewowe. Pol Prz Radiol. 1998, 63, 83-87.

15. Ferlay J. International Agency for research on Cancer, WHO. GLOBOCAN 2002: cancer incidence, morality and prevelence worldwide [electronic resource] Lyon: IARCPress, 2004.

16. Wronkowski Z. Chmielarczyk W. Zwierko M. Samobadanie piersi. Służba Zdrowia. 2000, 24/26, p. 2926-2929.

17. Woźniak I. Wiedza o schorzeniach nowotworowych narządów kobiecych i postawy kobiet wobec badań profilaktycznych. Probl Pielęg. 2008, 16, p.136-139.

18. Spaczyński M. i wsp. Women's social conditions and their participation in Cervical Cancer Population Screening program in Poland. Ginekol Pol. 2009, 80, s. 833-838.

19. Spaczyński M. i wsp. Uczestnictwo kobiet w Populacyjnym Programie Profilaktyki i Wczesnego Wykrywania Raka Szyjki Macicy w latach 2007-2009. Ginekol Pol. 2010, 81, s. 655-663.

20. Nowicki A. Borowa I. Maruszak M. Zachowania zdrowotne kobiet w zakresie zapobiegania, wczesnego wykrywania stanów przedrakowych i raka szyjki macicy. Ginekol Pol. 2008, 79:840-849

21. Zieliński J. Rokosz M. Rak szyjki macicy - czy można zmniejszyć śmiertelność z powodu tej choroby w Polsce? Współcz Onkol. 2000, 4, 216-217.

22. Klasa-Mazurkiewicz D. Emerich J. Milczek T. Próba wyjaśnienia związku zaawansowania klinicznego raka szyjki macicy z długoletnim niezgłaszaniem się na kontrolne badanie ginekologiczne. Ginekol Pol. 2002, 73, 823-828.

23. Franco E. Schlecht N. Saslow D. The epidemiology of cervical cancer. Cancer J. 2003, 9, 348-359.

24. Knihinicka-Mercik Z. Kazimierczak I. Mess E. [et al.] Styl życia kobiet przed rozpoznaniem raka szyjki macicy. Onkol Pol. 2006, 9, 141-144. 